\title{
VARNOST, STABILNOST, ŽIVLJENJSKI SLOG: PREVLADUJOČA KARIERNA SIDRA GOSPODARJEV SLOVENSKIH TRŽNIH KMETIJ
}

\author{
dr. Eva Boštjančič \\ Oddelek za psihologijo, Filozofska fakulteta Univerze v Ljubljani \\ Aškerčeva 2, SI-1000 Ljubljana \\ e-mail: eva.bostjancic@ff.uni-lj.si \\ dr. Barbara Lampič \\ Oddelek za geografijo, Filozofska fakulteta Univerze v Ljubljani \\ Aškerčeva 2, SI-I000 Ljubljana \\ e-mail: barbara.lampic@ff.uni-lj.si
}

Izvirni znanstveni članek

COBISS 1.01

DOI: $10.4312 /$ dela.44.1.5-23

\section{Izvleček}

V prispevku smo opredelili prevladujoča karierna sidra gospodarjev na slovenskih tržno usmerjenih kmetijah. Prevladujeta sidri varnosti in stabilnosti ter sidro življenjskega sloga, kar kaže, da gospodarji še vedno želijo stabilno, varno in predvidljivo delovno okolje ter samostojnost in prožnost pri organizaciji svojega dela. Stopnja izraženosti kariernih sider opozarja na pomanjkanje upravljavskih sposobnosti kmetov in skromno prisotnost kariernega sidra izziva. Razvoj kmetijstva in velika konkurenčnost znotraj panoge od kmeta zahtevata neprestano premagovanje in reševanje izzivov, iskanje novih priložnosti in odgovorno vodenje kmetije.

Ključne besede: karierna sidra, kmetijstvo, gospodar na kmetiji, družbena geografija, Slovenija

\section{SAFETY, STABILITY AND LIFESTYLE: DOMINANT CAREER ANCHORS AMONG THE HEADS OF SLOVENIA'S MARKET ORIENTATED AGRICULTURAL HOLDINGS}

\footnotetext{
Abstract

The paper is identifying the dominant career anchors among the heads of Slovenia's market orientated agricultural holdings. The dominant anchors are the safety and stability anchors, followed by the lifestyle anchor. This suggests that the heads of Slovenian agricultural holdings want not only a stable, safe and predictable working environment, but also autonomy and a certain degree of flexibility in organising their work. The career
} 
anchors referred to in the agricultural holdings surveyed also indicate a lack of managerial skills among farmers, and there are only few references made to the challenge anchor. The development of agriculture and strong competition are now forcing Slovenian farmers to deal with several challenges, seek new opportunities and manage agricultural holdings in a responsible manner.

Key words: career anchors, agriculture, head of agricultural holding, human geography, Slovenia

\section{UVOD}

Z usmerjanjem razvoja kmetijstva se v Sloveniji ukvarjamo na različnih ravneh (spodbujanje inovativnih tehnoloških praks, razvoj trženja, povečevanje obsega pridelave, uvajanje novih pridelkov, spodbujanje diverzifikacije dohodka na kmetiji ipd.), pogosto pa pozabljamo na posameznika, v našem primeru na gospodarja kmetije. Niti v procesu izobraževanja niti kasneje se ne obravnava kmetovih sposobnosti, znanja, zmožnosti in stališč, ki predstavljajo osnovo za njegovo vedenje in odločitve, ki so povezane z načrtovanjem, vodenjem in organiziranjem dela na kmetiji.

Od gospodarjev kmetij danes pričakujemo hitro odzivnost, usmerjenost k spremembam in prilagodljivost tržnim trendom. Izhodišče raziskovanja so bila karierna sidra, saj zaobjamejo večino osebnostnih lastnosti in potez, s pomočjo katerih lahko strokovno usmerjamo profesionalni razvoj gospodarja kmetije. V prvi tovrstni raziskavi v Sloveniji smo želeli raziskati vlogo kariernih sider gospodarjev slovenskih tržnih kmetij pri njihovem razvoju, dodatno pa smo ločeno obravnavali še ekološke in konvencionalne pridelovalce. Področje karierne usmeritve je postalo eno ključnih področij za sistematično, načrtovano in posamezniku prilagojeno karierno svetovanje ter posledično za ustrezen karierni razvoj posameznikov v hitro spreminjajočem se okolju.

\section{I.I Razvojne težnje slovenskega kmetijstva}

Kmetijstvo je kljub številnim finančnim podporam in razmeroma utečenim ukrepom kmetijske politike vse bolj odvisno od posameznika (največkrat prav gospodarja), njegovih sposobnosti, potreb, idej in odločitev. Med odločilne dejavnike razvoja kmetijstva in kmetije gotovo sodijo naravne razmere oziroma pridelovalni pogoji, subvencijske sheme, struktura trga, povpraševanje itd., vse bolj pa se kaže, da je v obstoječih razmerah nadaljnji razvoj sektorja pomembno odvisen od osebnostnih sposobnosti in lastnosti posameznika.

Prehod iz socialističnega $v$ tržno gospodarstvo v Sloveniji je namreč prinesel radikalne spremembe v kmetovanju: od stabilnih razmer, povezanih z zajamčenimi administrativnimi cenami številnih kmetijskih produktov v socializmu, do pridružitve Slovenije k EU in hitrega prevzemanja reform in ukrepov evropske skupne kmetijske politike (Knežević Hočevar, 2015). Zadnja leta spremljamo ukinjanje zajamčenih odkupnih cen ter postopno zniževanje kmetijskih plačil (subvencij), ki se bo v programskem obdobju 2014-2020 še nadaljevalo. 
Pri usmerjanju razvoja kmetijske dejavnosti čedalje bolj izpostavljamo potrebo po trajnostno zasnovanem razvoju. Ta naj bo gospodarsko spodbuden (in predvsem v pridelovalnem smislu uspešen), okoljsko odgovoren (kmetijstvo ima lahko vlogo obremenjevalca okolja ter pomembnega vzdrževalca kulturne pokrajine in biotske raznovrstnosti) in hkrati prispeva $\mathrm{k}$ družbenemu in regionalnemu razvoju podeželja (Slabe Erker in sod., 2015; Klemenčič, Lampič, Potočnik Slavič, 2008; Lampič, 2005; Potočnik Slavič, 2010).

Število slovenskih kmetij upada: po popisnih podatkih iz leta 2010 imamo še 74.646 kmetijskih gospodarstev, obseg kmetijskih zemljišč v uporabi (KZU) ostaja v zadnjem desetletju bolj ali manj nespremenjen, se pa zaradi strukturnih sprememb in specializacije v kmetijski dejavnosti nekoliko povečujeta povprečna velikost kmetije $(6,4$ ha KZU leta 2010) in delež kmetij, večjih od 30 ha KZU (Popis kmetijskih gospodarstev 2000 in 2010). Z omenjenimi spremembami je povezana tudi vse večja tržna naravnanost kmetij. Po zadnjih popisnih podatkih jih 29.999 (oziroma 40 \% vseh kmetij) prideluje pretežno za trg (Popis kmetijskih gospodarstev 2000 in 2010), dejansko število tržno naravnanih kmetij pa je še precej večje. Poleg vse bolj usmerjene oziroma specializirane pridelave se uveljavljajo tudi novejši pristopi (npr. ekološki način pridelave), za katere se pogosteje odločajo kmetje, ki pri svojem delu iščejo izzive in inovativne poti.

Pri ekoloških kmetovalcih je dokazano njihovo večje zadovoljstvo (z delom na kmetiji) in tudi večje zadovoljstvo njihovih družin in delavcev (Gassner, Freyer, Leitner, 2008; Shreck, Getz, Feenstra, 2006; Jansen, 2000), saj ekološko kmetijstvo deluje kot spodbujevalec inovacij v razvoju podeželja (Offermann, Nieberg, 2000; Organic marketing ..., 2004). Ekološko kmetijstvo je v zadnjih petnajstih letih v Sloveniji doživelo precejšen razmah. Leta 2014 so ekološka kmetijska zemljišča predstavljala skoraj 8,7 \% vseh KZU (41.237 ha KZU), 3298 ekoloških kmetij pa 4,6 \% vseh slovenskih kmetij (Analiza stanja ..., 2015). Pred desetletjem smo s pripravo Akcijskega načrta za razvoj ekološkega kmetijstva v Sloveniji do leta 2015 ambiciozno načrtovali 20 \% ekološko obdelanih KZU, 15 \% ekoloških kmetij in kar 10 \% (slovenskih) ekoloških živil v strukturi skupne prodaje (Akcijski načrt ..., 2005). Številčna rast ekoloških površin in kmetij je vsaj nekoliko sledila zastavljenim ciljem, na področju pridelave pa ekološko kmetijstvo ni upravičilo pričakovanj. Razlog za takšno stanje lahko vsaj deloma najdemo tudi v neustrezni zastopanosti kariernih sider med slovenskimi kmeti.

\section{I.2 Teorija kariernih sider}

Karierno sidro predstavlja značilno specifično podobo o lastnih sposobnostih, potrebah, vrednotah, stališčih in motivih, ki vplivajo na težnjo posameznika k opravljanju določenih poklicev oziroma delovnih nalog (Schein, 1974; 1996). Schein (1974) je opredelil osem kariernih sider (preglednica 1), ki predstavljajo samozaznane sposobnosti in talente ter predstavljajo pomemben del posameznikove karierne usmeritev (DeLong, 1982). Običajno pri posamezniku prevladuje eno sidro (Schein, 1978), a DeLong (1982) ter Butler in Waldroop (1999) ugotavljajo, da običajno eno do tri sidra skupaj oblikujejo posameznikovo kariero in delovno učinkovitost. 


\section{Preglednica 1: Predstavitev značilnosti kariernih sider}

\section{Table 1: The characteristics of career anchors}

\begin{tabular}{|c|c|c|c|}
\hline $\begin{array}{l}\text { Karierno } \\
\text { sidro }\end{array}$ & $\begin{array}{l}\text { Osnovne značilnosti } \\
\text { posameznikov }\end{array}$ & Vrste in načini dela & Motivacija za delo \\
\hline $\begin{array}{l}\text { Tehnično- } \\
\text { funkcionalno } \\
\text { sidro }\end{array}$ & $\begin{array}{l}\text { Pogosto se specializirajo in pois- } \\
\text { tovetijo z vsebino dela, predvsem } \\
\text { s tehničnimi in funkcionalnimi } \\
\text { področji, na katerih so uspešni, } \\
\text { ter razvijajo svoje spretnosti. }\end{array}$ & $\begin{array}{l}\text { V prvi vrsti jim je pomembna } \\
\text { vsebina dela. Potrebujejo } \\
\text { izziv in naloge, pri katerih } \\
\text { lahko izkazujejo in razvijajo } \\
\text { svoje spretnosti in talente. }\end{array}$ & $\begin{array}{l}\text { Potrebujejo predvsem } \\
\text { priznanje in potrditev } \\
\text { s strani kolegov iste } \\
\text { stroke. }\end{array}$ \\
\hline $\begin{array}{l}\text { Menedžersko } \\
\text { sidro }\end{array}$ & $\begin{array}{l}\text { Poudarjajo poznavanje različnih } \\
\text { področij. Zanima jih vodenje, } \\
\text { sposobni so prevzemati } \\
\text { odgovornost in željo napredovati. }\end{array}$ & $\begin{array}{l}\text { Želijo imeti veliko } \\
\text { odgovornosti, izzive in } \\
\text { možnosti za vodenje. } \\
\text { Delovno mesto jim mora } \\
\text { omogočati, da se lahko prek } \\
\text { svojega dela istovetijo z } \\
\text { organizacijo. }\end{array}$ & $\begin{array}{l}\text { Potrebujejo vedno več } \\
\text { odgovornosti ter možnost } \\
\text { vodenja. Želijo prispevati } \\
\text { k uspehu podjetja, hkrati } \\
\text { biti nagrajeni z visokim } \\
\text { dohodkom. }\end{array}$ \\
\hline $\begin{array}{l}\text { Sidro } \\
\text { samostojnosti } \\
\text { in neodvisnosti }\end{array}$ & $\begin{array}{l}\text { Delo želijo opravljati na svoj } \\
\text { način, v svojem lastnem ritmu } \\
\text { in s svojimi merili. Ne prenesejo } \\
\text { omejitev. }\end{array}$ & $\begin{array}{l}\text { Najraje imajo jasno opisano, } \\
\text { časovno določeno delo, } \\
\text { najpogosteje se nagibajo k } \\
\text { neodvisnim poklicem. }\end{array}$ & $\begin{array}{l}\text { Želijo imeti proste roke } \\
\text { pri izbiri sredstev in } \\
\text { načinu dela. }\end{array}$ \\
\hline $\begin{array}{l}\text { Sidro varnosti } \\
\text { in stabilnosti }\end{array}$ & $\begin{array}{l}\text { Iščejo službo, ki jim zagotavlja } \\
\text { trajno delovno razmerje, dobre } \\
\text { pokojninske sheme in druge } \\
\text { ugodnosti. Odgovornost za ka- } \\
\text { riero so pripravljeni prepustiti } \\
\text { delodajalcu. } \\
\end{array}$ & $\begin{array}{l}\text { Želijo si predvsem stabilno } \\
\text { in predvidljivo delo in dobre } \\
\text { delovne razmere. }\end{array}$ & $\begin{array}{l}\text { S strani delodajalca } \\
\text { pričakujejo stalne } \\
\text { spodbude ter priznanje } \\
\text { za lojalnost. } \\
\end{array}$ \\
\hline $\begin{array}{l}\text { Sidro } \\
\text { podjetniške } \\
\text { ustvarjalnosti }\end{array}$ & $\begin{array}{l}\text { Čutijo potrebo po lastnih pro- } \\
\text { jektih (razvoju lastnih izdelkov } \\
\text { in storitev) in odpiranju lastnih } \\
\text { podjetij. Imajo tudi močno izra- } \\
\text { ženo težnjo po dokazovanju (na } \\
\text { svojem strokovnem področju). } \\
\end{array}$ & $\begin{array}{l}\text { Pogosto odpirajo lastna } \\
\text { podjetja in iščejo nove } \\
\text { priložnosti. }\end{array}$ & $\begin{array}{l}\text { Težijo k širjenju } \\
\text { poslovanja, obsega dela } \\
\text { ter k vedno večjemu } \\
\text { zaslužku. }\end{array}$ \\
\hline $\begin{array}{l}\text { Sidro } \\
\text { predanosti }\end{array}$ & $\begin{array}{l}\text { Pri svojem delu želijo pomagati } \\
\text { drugim. Svoje osebne vrednote } \\
\text { pogosto enačijo s poklicnimi. }\end{array}$ & $\begin{array}{l}\text { Pri delu pričakujejo možnost } \\
\text { vplivanja na organizacijo } \\
\text { ali družbo v smislu njihovih } \\
\text { vrednot. }\end{array}$ & $\begin{array}{l}\text { Želijo, da njihove } \\
\text { vrednote sprejema širši } \\
\text { krog ljudi. Potrebujejo } \\
\text { priznanje s strani } \\
\text { kolegov ali nadrejenih. }\end{array}$ \\
\hline Sidro izziva & $\begin{array}{l}\text { Iščejo izziv, želijo premagovati } \\
\text { nemogoče ovire, reševati nereš- } \\
\text { ljive probleme, premagati moč- } \\
\text { nega nasprotnika. }\end{array}$ & $\begin{array}{l}\text { Pri svojem delu hočejo } \\
\text { preizkušati svoje zmogljivosti } \\
\text { in sposobnosti. }\end{array}$ & $\begin{array}{l}\text { Motivira jih raznoliko } \\
\text { delo. }\end{array}$ \\
\hline $\begin{array}{l}\text { Sidro } \\
\text { življenjskega } \\
\text { sloga }\end{array}$ & $\begin{array}{l}\text { Pomembna jim je uravnoteženost } \\
\text { med osebnim in poklicnim } \\
\text { življenjem ter povezanost } \\
\text { zadovoljevanja potreb } \\
\text { posameznika, družine in kariere. }\end{array}$ & $\begin{array}{l}\text { Pri delu si želijo prožnosti } \\
\text { (gibljiv delovni čas, } \\
\text { prilagodljivo delo (npr. delo } \\
\text { doma ipd.). }\end{array}$ & $\begin{array}{l}\text { Pričakujejo, da njihov } \\
\text { delodajalec kaže tako } \\
\text { spoštovanje do osebnih } \\
\text { in družinskih zahtev kot } \\
\text { tudi razumevanje njiho- } \\
\text { vih individualnih želja. }\end{array}$ \\
\hline
\end{tabular}

Vir/Source: Brečko, 2006 
Kniveton (2004) in Nordvik (1996) sta opozorila, da s sistemom kariernih sider posameznikov ne moremo kategorizirati, temveč lahko le prepoznamo njihovo karierno usmeritev, ki jih vodi po poklicni poti. S tem lahko razvojne načrte prilagodimo posamezniku, posledično pa le-ta doživlja manj stresa. Strokovnjaki namreč vse bolj ugotavljajo, da je uspešen tisti, ki je zadovoljen s svojo izbiro poklica, da lahko uresničuje osebne vrednote, ima jasne cilje in oblikovano samopodobo (Brečko, 2008).

Karierna sidra so bila predmet številnih raziskav v različnih delovnih okoljih tako v Sloveniji kot drugje po svetu. Rezultati kažejo na pomembne povezave s starostjo, spolom in kulturnim okoljem, iz katerega posamezniki prihajajo (Coetzee, Schreuder, 2009; Jiang, Klein, Balloun, 2001; Suutari, Taka, 2004). Če primerjamo karierna sidra glede na starost oziroma generacijo, ki ji posameznik pripada, se pokaže, da v Sloveniji s starostjo narašča prisotnost sidra življenjskega sloga in sidro izziva (Brečko, 2008). Pri generaciji X (posamezniki, rojeni med leti 1965 in 1978) je bil najprej opazen porast sidra življenjskega sloga (velika potreba po usklajevanju družinskega in poklicnega življenja). Pri generaciji Y (posamezniki, rojeni med leti 1979 in 1999) poleg tega sidra narašča še sidro izziva, $\mathrm{k}$ čemur je najverjetneje pripomogla raznolikost izzivov v okolju ter njihova intenziteta (Brečko, 2004). Schein (1996) pa poudarja, da se v obdobju srednje in pozne starosti karierna sidra začnejo stabilizirati in ostajajo relativno stabilna.

Prevladujoča karierna sidra naj bi se povezovala tudi z določeno vrsto poklicev. V Sloveniji je Brečkova (2008) izvedla longitudinalno študijo, ki je omogočila vpogled v povezave med različnimi poklici in prevladujočimi kariernimi sidri. Pri direktorjih podjetij je prevladovalo menedžersko sidro, pri vodjih oddelkov, inženirjih in ekonomistih tehnično-funkcionalno sidro, pri zaposlenih v pravni službi sidro samostojnosti in neodvisnosti, medtem ko je sidro varnosti in stabilnosti najpogosteje prevladovalo pri organizatorjih dela, kadrovskih in upravnih delavcih. Tovrstna raziskava med kmetovalci $\mathrm{v}$ Sloveniji še ni bila izvedena.

Na splošno velja, da so najbolj učinkoviti ljudje, ki so zaposleni na delovnih mestih, za katere imajo ustrezne kompetence, in so hkrati zadovoljni s svojim delom. Schein (1974) je z modelom kariernih sider pojasnil, da si s pomočjo kariernih sider posameznik izbere najbolj zaželeno karierno razvojno pot, kar v našem primeru pomeni, da naj bi se želje, interesi in osebnostne lastnosti gospodarja kmetije skladali z njegovim delovnim okoljem. Predpostavimo lahko, da če se posameznikova karierna sidra ne ujemajo z lastnostmi delovnega okolja, lahko pride pogosteje do tesnobnosti, stresa, nezadovoljstva z delom ter želje po menjavi delovnega mesta (Feldman, Bolino, 1996; Jiang, Klein, Balloun, 2001).

Osrednji namen raziskave je bil ugotoviti izraženost prevladujočih kariernih sider (osebnostnih lastnosti) gospodarjev tržnih kmetij v Sloveniji. Na osnovi ugotovitev smo podali usmeritve, v katerih elementih in kako je potrebno vpeljati spremembe in ukrepe za podporo gospodarjem kmetij pri njihovem delu in osebnem zadovoljstvu. Analizirali smo tudi povezave med demografsko vitalnostjo kmečkih gospodinjstev, starostjo gospodarjev, njihovo kmetijsko izobrazbo, zadovoljstvom z rezultati dela na kmetiji in obsegom dohodka gospodinjstva iz kmetijstva. Znotraj kmetijstva smo želeli izpostaviti še hitro razvijajoči sektor ekološkega kmetijstva, zato smo ugotavljali še morebitne razlike med gospodarji ekoloških in konvencionalnih kmetij. 


\section{METODE DELA}

Pri ugotavljanju zastopanosti kariernih sider v določenem poklicu oziroma podjetju uporabljamo vprašalnik kariernih sider (ang. Career Orientations Inventory; Brečko, 2004, 2008; Schein, 1990). Originalni vprašalnik vsebuje 40 postavk, ki opisujejo osem kariernih sider:

- tehnično-funkcionalno sidro (npr. »Želim si postati tako dober v kmetovanju, da bi ljudje lahko iskali moje strokovne nasvete.«);

- menedžersko sidro (npr. »Želim si voditi kmetijo ter odločati o stvareh, ki bi vplivale na veliko ljudi.«);

- $\quad$ sidro samostojnosti in neodvisnosti (npr. »Želim si tako delo, ki mi dopušča svobodo pri delu.«);

- sidro varnosti in stabilnosti (npr. »Varnost in stabilnost na kmetiji sta mi pomembnejši kot svoboda in neodvisnost.«);

- $\quad$ sidro predanosti (npr. »Pri delu se počutim najbolj izpolnjenega, kadar lahko uporabljam svoje talente, da pomagam drugim.«);

- sidro izziva (npr. »Želim si takšno delo na kmetiji, kjer bom lahko reševal zelo zahtevne in izzivalne probleme ter situacije.«) in

- sidro življenjskega sloga (npr. »Vedno sem iskal takšne delovne priložnosti, ki omogočajo večjo usklajenost z osebnimi in družinskimi obveznostmi.«).

V skladu z namenom naše raziskave o prevladujočih kariernih sidrih gospodarjev kmetij smo vprašalnik prilagodili tako, da smo določene besede iz poslovnega sveta nadomestili z ustreznimi vzporednimi pojmi s področja kmetovanja. Zaradi dolžine vprašalnika in pričakovane strokovnosti vseh anketirancev smo izločili sidro podjetniške ustvarjalnosti (pet trditev oziroma postavk), tako da smo na koncu ugotavljali zastopanost sedmih kariernih sider.

Anketiranci so s pomočjo šeststopenjske lestvice (1 - nikakor ne velja zame, 6 - popolnoma velja zame) ocenjevali strinjanje s posamezno trditvijo. Vprašalnik meri, katero sidro je pri posamezniku prevladujoče. Za preverjanje notranje zanesljivosti vključenih lestvic smo uporabili Cronbachov $\alpha$ koeficient: tehnično-funkcionalno sidro $(\alpha=0,64)$, menedžersko sidro $(\alpha=0,52)$, sidro samostojnosti in neodvisnosti $(\alpha=0,60)$, sidro varnosti in stabilnosti $(\alpha=0,50)$, sidro predanosti $(\alpha=0,77)$, sidro izziva $(\alpha=0,84)$ in sidro življenjskega sloga $(\alpha=0,70)$.

V raziskavi je sodelovalo 273 slovenskih gospodarjev kmetij, in sicer 169 s konvencionalnih in 104 z ekoloških kmetij. V raziskavo smo vključili kmetije, ki so vsaj v določenem segmentu tudi tržno naravnane (tj. da so v okviru vprašalnika navedli pridelke in proizvode, ki jih tržijo), saj razvoj sektorja pomembno povezujemo s pridelovalno vlogo kmetijstva. Anketiranje ekoloških kmetov je potekalo v letih 2011-2012, anketiranje konvencionalnih kmetovalcev pa leta 2013. Anketiranje ekoloških kmetov smo izvajali v okviru raziskave CRP Ekonomika ekoloških kmetij (Lampič in sod., 2013), kjer smo preučevali predvsem tržni vidik ekološke pridelave v Sloveniji, vprašalnik o kariernih sidrih pa je predstavljal dopolnitev osnovnega vprašalnika o ekonomiki ekoloških tržnih kmetij. Terensko raziskavo 
kariernih sider gospodarjev konvencionalnih tržnih kmetij smo izvedli leto kasneje, in sicer na naključno izbranem vzorcu tržnih kmetij. Poleg osnovnega vprašalnika kariernih sider smo od kmetov pridobili še osnovne informacije o značilnostih kmečkega gospodinjstva (število in starost članov), značilnostih gospodarja (starost, izobrazba, zaposlitveni status) in kako vidijo prihodnost svoje kmetije. Zaprosili smo jih tudi, naj na petstopenjski lestvici ocenijo svoje osebno zadovoljstvo z rezultati, ki jih daje kmetija.

Osnovne značilnosti vzorca gospodarjev so prikazane v preglednici 2. Opazimo nekatere posebnosti našega vzorca, npr. visok delež gospodarjev s kmetijsko izobrazbo in velik delež zaposlenih na kmetiji, kar povezujemo z izborom (vsaj deloma) tržno usmerjenih kmetij. Pri obdelavi podatkov smo združili anketirance glede na starost le v dve skupini in ju v nadaljevanju primerjali med seboj - mlajše (mlajši od 50 let, 51 \%) in starejše (starejši od 50 let, $49 \%$ ).

Preglednica 2: Zastopanost gospodarjev konvencionalnih in ekoloških kmetij $(N=273)$ glede na demografske spremenljivke

Table 2: The distribution of heads of market-oriented agricultural holdings (conventional and organic; $N=273$ ) according to selected demographic variables

\begin{tabular}{|c|c|c|c|c|c|c|c|}
\hline \multirow[t]{2}{*}{ Spremenljivka } & & \multicolumn{2}{|c|}{$\begin{array}{l}\text { Konvencionalni } \\
\text { kmetje }\end{array}$} & \multicolumn{2}{|c|}{ Ekološki kmetje } & \multicolumn{2}{|c|}{ Skupaj } \\
\hline & & $N$ & $\%$ & $N$ & $\%$ & $N$ & $\%$ \\
\hline \multirow{6}{*}{ Starost gospodarja } & Do 35 let & 21 & 12,4 & 13 & 12,5 & 34 & 12,5 \\
\hline & 36 do 50 let & 69 & 40,8 & 36 & 34,6 & 105 & 38,5 \\
\hline & 51 do 60 let & 46 & 27,2 & 35 & 33,7 & 81 & 29,7 \\
\hline & 61 do 70 let & 21 & 12,4 & 18 & 17,3 & 39 & 14,3 \\
\hline & Nad 70 let & 12 & 7,1 & 2 & 1,9 & 14 & 5,1 \\
\hline & Skupaj & 169 & 100,0 & 104 & 100,0 & 273 & 100,0 \\
\hline \multirow{4}{*}{$\begin{array}{l}\text { Dosežena stopnja } \\
\text { formalne izobrazbe }\end{array}$} & OŠ ali manj & 28 & 18,2 & 11 & 10,7 & 39 & 15,2 \\
\hline & Poklicna, srednja šola & 114 & 74,0 & 75 & 72,8 & 189 & 73,5 \\
\hline & $\begin{array}{l}\text { Višja, visoka, mag., } \\
\text { doktorat }\end{array}$ & 12 & 7,8 & 17 & 16,5 & 29 & 11,3 \\
\hline & Skupaj & 154 & 100,0 & 103 & 100,0 & 257 & 100,0 \\
\hline \multirow{3}{*}{ Kmetijska izobrazba } & $\mathrm{Da}$ & 70 & 50,4 & 26 & 25,7 & 96 & 40,0 \\
\hline & $\mathrm{Ne}$ & 69 & 49,6 & 75 & 74,3 & 144 & 60,0 \\
\hline & Skupaj & 139 & 100,0 & 101 & 100,0 & 240 & 100,0 \\
\hline \multirow{6}{*}{ Gospodarjev status } & Dijak, študent & 1 & 0,8 & 0 & 0,0 & 1 & 0,4 \\
\hline & Redno zaposlen & 14 & 11,6 & 20 & 19,4 & 34 & 15,2 \\
\hline & Upokojenec & 16 & 13,2 & 19 & 18,4 & 35 & 15,6 \\
\hline & Nezaposlen & 0 & 0,0 & 2 & 1,9 & 2 & 0,9 \\
\hline & $\begin{array}{l}\text { Kmet, zaposlen doma } \\
\text { na kmetiji }\end{array}$ & 90 & 74,4 & 62 & 60,2 & 152 & 67,9 \\
\hline & Skupaj & 121 & 100,0 & 103 & 100,0 & 224 & 100,0 \\
\hline
\end{tabular}

Na razvojno naravnanost kmetije in predvsem njihovo tržno pridelavo vpliva vrsta dejavnikov. Slabetova (2015) na ravni kmetije opredeljuje kot odločilna dva sklopa 
dejavnikov, in sicer t. i. pridelovalne in organizacijske kapacitete kmetije. Ugotavlja, da je od organizacijskih kapacitet kmetije odvisno, kako bodo na kmetiji gospodarji upravljali z naravnimi viri in razpoložljivimi pridelovalnimi sredstvi. Znotraj organizacijskih kapacitet opredeljuje finančni in človeški potencial kmetije, v katerem nakaže potrebo po upoštevanju upravljavskega profila gospodarja (Slabe, 2015).

Vsekakor velja naš naključni vzorec gospodarjev tržnih kmetij primerjati z dejansko demografsko vitalnostjo kmetijskih gospodinjstev, izobrazbo oziroma kmetijsko izobrazbo kmetov (gospodarjev), s prihodnostjo kmetij in z (osebnim) zadovoljstvom kmetov z rezultati, ki jih daje njihovo delo na kmetiji. Opredelitev demografske vitalnosti kmetije je kompleksna in označuje demografsko živost celotnega kmečkega gospodinjstva, ki jo opredelimo s številom, starostjo in zaposlitvenim statusom družinskih članov (Klemenčič, Lampič, Potočnik Slavič, 2008; Lampič, 2008). Uradna statistika teh podatkov ne beleži, so pa ključnega pomena za razvojne odločitve kmetije, ki so praviloma dolgoročne in povezane z delovno silo. Dosedanje raziskave kažejo, da je delež demografsko perspektivnih kmetij višji med usmerjenimi in specializiranimi, tudi med kmetijami, ki si povečujejo dohodek z dopolnilnimi dejavnostmi (Nienaber, Potočnik Slavič, 2013), in ekološkimi kmetijami (Slabe in sod., 2010; Lampič in sod., 2013, Lampič, Slabe, 2013).

Še pred leti je bila skromna formalna izobrazba slovenskega kmeta ena ključnih slabosti in ovir za gospodarski razvoj kmetijstva. Delež gospodarjev zgolj s praktičnimi izkušnjami je leta 2000 znašal še 84 \%, leta 2010 pa se je zmanjšal na $64 \%$ (Popis kmetijstva 2000 in 2010). Še pomembnejše je spremljanje podatkov o formalni kmetijski izobrazbi, ki se hitro izboljšuje, predvsem v kmetijsko bolj razvitih regijah (npr. Pomurski statistični regiji). Leta 2010 je imelo formalno kmetijsko izobrazbo 8,8 \% vseh gospodarjev (2000: 5,7 \%), potreba po novih znanjih pa se kaže predvsem v deležu kmetov, ki so opravili različne dodatne tečaje in izobraževanja, saj se je ta povečal z $8 \%$ (2000) na kar $27 \%$ (2010).

Za prihodnost kmetije, kot jo ocenjuje nosilec kmetijskega gospodarstva, ima zagotovljeno nasledstvo veliko vlogo. Eden glavnih problemov v življenjskem ciklusu družinske kmetije je medgeneracijsko nasledstvo, s katerim se zagotavlja nadaljevanje 'tradicije' kmetijske dejavnosti skozi generacije (Bohak, 2011). Dosedanje raziskave v Sloveniji kažejo, da je nadaljevanje kmetovanja oziroma nadaljnji razvoj in uvajanje novosti mnogo bolj izražen med že usmerjenimi, specializiranimi in tržnimi kmetijami. Tako smo v raziskavi med kmeti na območju Mestne občine Ljubljana (189 kmetij; Lampič, 2008) zabeležili kar tretjino takšnih, ki v kmetijstvu ne vidijo prave prihodnosti in pričakujejo, da bo kmetijska dejavnost v nekaj letih zamrla. Po drugi strani smo npr. med ekološkimi pridelovalci (242 ekoloških kmetij; Slabe, Lampič, Juvančič, 2011) zabeležili le 14 \% tistih, ki dolgoročno ne vidijo prihodnosti za svojo kmetijo. Med tržnimi kmetijami, vključenimi v našo raziskavo, je ta delež znašal le 5,2 \% (od 271 odgovorov).

Vprašanje o zadovoljstvu z rezultati kmetije smo naslovili na gospodarja in odraža njegovo osebno stališče in videnje rezultatov dela. To vprašanje smo v raziskavo vključili predvsem zato, ker so predhodne študije pokazale, da je ustrezna karierna usmeritev povezana tudi z delovno učinkovitostjo (Butler, Waldroop, 1999) ter zadovoljstvom pri delu (Brečko, 2008; Jiang, Klein, Balloun, 2001). Že pri raziskavi ekoloških tržnih kmetij 
(Lampič in sod., 2013) se je pokazalo, da je lahko razumevanje zadovoljstva z delom na kmetiji in rezultati, ki jih ta daje, zelo subjektivno. Pričakovali smo, da bodo gospodarji ekoloških kmetij bolj zadovoljni z rezultati svojega dela kot konvencionalni.

\section{REZULTATI}

Uvodoma so predstavljene opisne statistike. Normalnost razporeditve rezultatov lestvic smo testirali s Shapiro-Wilkovim testom, ki je primeren za napovedovanje normalnosti razporeditve pri manjših vzorcih. S krepkim tiskom so označene vrednosti, ki kažejo statistično pomembno odstopanje od normalne razporeditve na ravni tveganja $5 \%$.

Preglednica 3: Opisne statistike in rezultati testiranja normalnosti razporeditev vključenih postavk ter Vprašalnika kariernih sider pri vzorcu kmetij $(N=273)$

Table 3: Descriptive statistics and results of testing distribution of included items and Career Anchors Questionnaire of included agricultural holdings $(N=273)$

\begin{tabular}{|l|c|c|c|c|c|c|c|c|}
\cline { 2 - 10 } \multicolumn{1}{c|}{} & Min & Max & M & SD & Asim. & Spl. & W & p \\
\hline Zadovoljstvo & 1 & 5 & 3,64 & 0,94 & $-0,79$ & 0,82 & 0,854 & $\mathbf{0 , 0 0 0}$ \\
\hline Vitalnost & 1 & 7 & 4,87 & 1,26 & $-0,76$ & $-0,07$ & 0,885 & $\mathbf{0 , 0 0 0}$ \\
\hline Delež dohodka iz kmetijstva & 0 & 100 & 60,62 & 27,09 & $-0,11$ & $-0,90$ & 0,949 & $\mathbf{0 , 0 0 0}$ \\
\hline Vprašalnik kariernih sider \\
\hline Tehnično-funkcionalno & 8 & 30 & 21,34 & 4,56 & $-0,43$ & $-0,31$ & 0,976 & $\mathbf{0 , 0 0 0}$ \\
\hline Menedžersko & 6 & 29 & 19,25 & 4,52 & $-0,21$ & $-0,02$ & 0,986 & $\mathbf{0 , 0 1 5}$ \\
\hline Samostojnost in neodvisnost & 11 & 30 & 22,65 & 4,12 & $-0,58$ & 0,25 & 0,966 & $\mathbf{0 , 0 0 0}$ \\
\hline Varnost in stabilnost & 12 & 24 & 23,63 & 3,60 & $-0,35$ & 0,10 & 0,977 & $\mathbf{0 , 0 0 0}$ \\
\hline Predanost & 6 & 30 & 20,20 & 5,08 & $-0,29$ & $-0,17$ & 0,984 & $\mathbf{0 , 0 0 7}$ \\
\hline Izziv & 5 & 30 & 18,17 & 6,00 & 0,02 & $-0,79$ & 0,981 & $\mathbf{0 , 0 0 2}$ \\
\hline Življenjski slog & 7 & 30 & 22,85 & 4,43 & $-0,76$ & 0,89 & 0,958 & $\mathbf{0 , 0 0 0}$ \\
\hline
\end{tabular}

Legenda: Min = minimum; Max = maksimum; : srednja vrednost; SD = standardni od klon; Asim. = asimetrija; Spl. = sploščenost; $W=$ Shapiro-Wilkov koeficient; $p=$ statistična pomembnost

Legend: Min = minimum; Max = maximum; $S D=$ standard deviation; $M=$ mean value; Asim . = asymmetry; Spl. = skewness; $W=$ Shapiro-Wilk coefficient; $p=$ statistical significance

Iz preglednice 3 je razvidno, da imajo vse lestvice razporeditev drugačno od normalne, zato smo v nadaljevanju za preverjanje statistične pomembnosti razlik med skupinama in povezav med vprašalnikom ter drugimi obravnavanimi neodvisnimi in odvisnimi spremenljivkami uporabili neparametrične postopke. V prvem koraku smo pogledali, kakšen profil kariernih sider imajo gospodarji preučevanih tržnih kmetij v Sloveniji ter ali obstajajo razlike v izraženosti profila med gospodarji konvencionalnih in ekoloških kmetij (slika 1). 
Slika 1: Razlike v prevladujočem profilu kariernih sider med gospodarji konvencionalnih in ekoloških kmetij $(N=273)$

Figure 1: Differences on prevailing career anchors' profile between heads of conventional and organic farms $(N=273)$

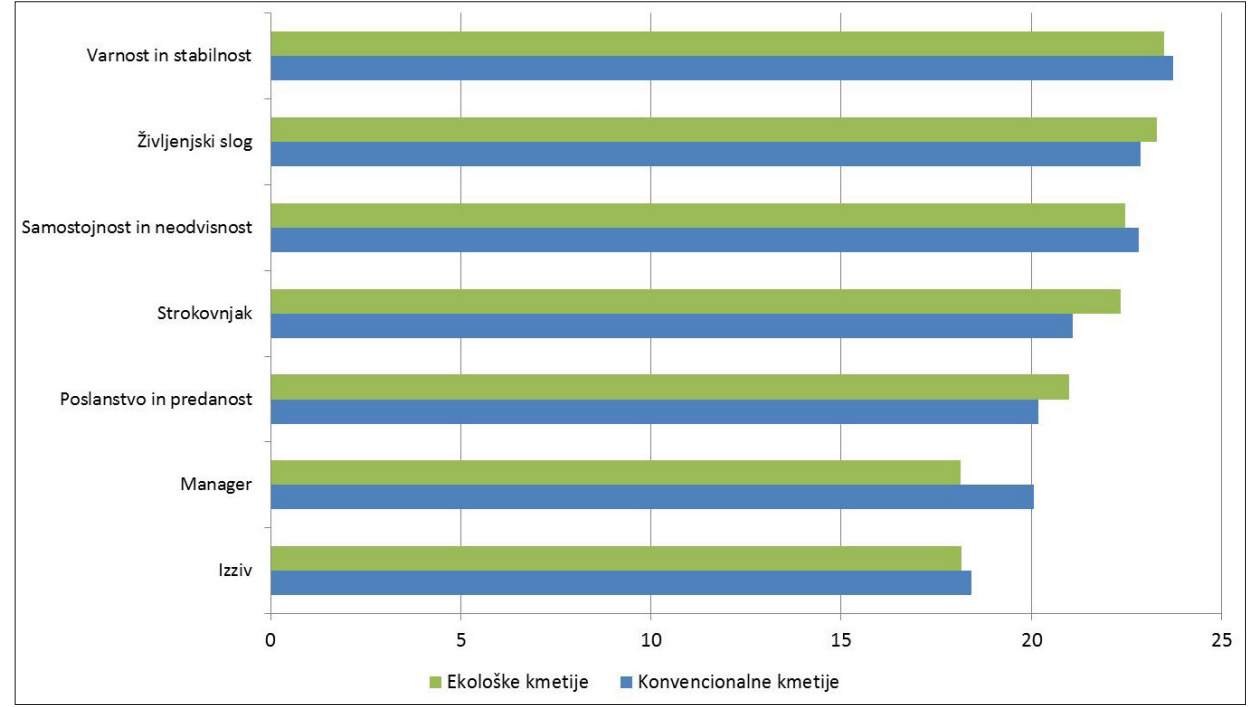

Pri gospodarjih preučevanih konvencionalnih in ekoloških kmetij je najbolj izraženo karierno sidro varnosti in stabilnosti, sledita sidri življenjskega sloga ter samostojnosti in neodvisnosti. Gospodarji anketiranih slovenskih kmetij tako najpogosteje iščejo delo, ki jim omogoča dolgoročno varnost ter stabilne in predvidljive delovne razmere. Pri gospodarjih ekoloških kmetij izraziteje prednjači tehnično-funkcionalno sidro (značilno za to sidro je »... biti dober strokovnjak na svojem področju «), s katerim posameznik poudarja pomembnost tehnične in vsebinske plati dela. Pri obeh obravnavanih skupinah je visoko izraženo tudi sidro življenjskega sloga, ki kaže željo po uspešnem usklajevanju dela in zasebnega življenja. Obe skupini imata najmanj izraženo sidro izziva, kar nakazuje, da anketiranim gospodarjem na splošno primanjkuje notranje potrebe po izzivih, ne čutijo želje po odkrivanju novih področij, oziroma si redkeje želijo preizkušanja drugačnih načinov in oblik dela. Razlike v izraženosti kariernih sider med obema skupinama gospodarjev kmetij so statistično pomembne le pri menedžerskem kariernem sidru $(F(1,271)=7,05 ; p$ $<0,01)$, kjer se višje ocenjujejo gospodarji konvencionalnih kmetij $\left(M_{\text {konv }}=20,07, S D_{\text {konv }}\right.$ $\left.=4,03 ; M_{\text {eko }}=18,13, S D_{\text {eko }}=5,21\right)$.

$\mathrm{V}$ nadaljevanju sledijo prikazi primerjav rezultatov med anketiranimi gospodarji tržnih konvencionalnih in ekoloških kmetij glede na ocenjevanje njihovega zadovoljstva $\mathrm{z}$ rezultati, ki jih daje kmetija, ocena demografske vitalnosti kmetije ter vizija gospodarjev o prihodnosti razvoja kmetije. 
Preglednica 4: Razlike v zadovoljstvu gospodarjev konvencionalnih in ekoloških kmetij z rezultati, ki jih daje njihova kmetija

Table 4: Differences between the heads of conventional and organic farms regarding their satisfaction with their farms' outputs

\begin{tabular}{|c|c|c|c|c|c|c|}
\hline \multirow[b]{2}{*}{ Stopnja zadovoljstva } & \multicolumn{2}{|c|}{ Konvencionalni kmetje } & \multicolumn{2}{|c|}{ Ekološki kmetje } & \multicolumn{2}{|l|}{ Skupaj } \\
\hline & $\mathbf{N}$ & $\%$ & $\mathbf{N}$ & $\%$ & $\mathbf{N}$ & $\%$ \\
\hline Nezadovoljen & 3 & 1,8 & 8 & 7,8 & 11 & 4,1 \\
\hline Delno nezadovoljen & 12 & 7,1 & 2 & 2,0 & 14 & 5,2 \\
\hline Srednje zadovoljen & 54 & 32,0 & 24 & 23,5 & 78 & 28,8 \\
\hline Delno zadovoljen & 78 & 46,2 & 50 & 49,0 & 128 & 47,2 \\
\hline Zadovoljen & 22 & 13,0 & 18 & 17,6 & 40 & 14,8 \\
\hline Skupaj & 169 & 100,0 & 102 & 100,0 & 271 & 100,0 \\
\hline
\end{tabular}

Iz preglednice 4 je razvidno, da je več kot $60 \%$ anketiranih gospodarjev kmetij zadovoljnih oziroma delno zadovoljnih z rezultati, ki jih daje njihova kmetija. Visoko zadovoljstvo je še nekoliko bolj izraženo med ekološkimi kmeti (66,6 \% vprašanih). Istočasno je v tej skupini 9,8 \% kmetov nezadovoljnih, med gospodarji konvencionalnih kmetij pa $8,9 \%$, kar kaže tudi na ustrezno primerljivost obeh skupin.

Preglednica 5: Razlike v demografski vitalnosti anketiranih konvencionalnih in ekoloških kmetij Table 5: Differences between conventional and organic farms regarding the demographic vitality

\begin{tabular}{|c|c|c|c|c|c|c|}
\hline \multirow{2}{*}{$\begin{array}{l}\text { Demografska } \\
\text { vitalnost }\end{array}$} & \multicolumn{2}{|c|}{ Konvencionalne kmetije } & \multicolumn{2}{|c|}{ Ekološke kmetije } & \multicolumn{2}{|l|}{ Skupaj } \\
\hline & $\mathbf{N}$ & $\%$ & $\mathbf{N}$ & $\%$ & $\mathbf{N}$ & $\%$ \\
\hline Manj perspektivne & 11 & 6,5 & 6 & 5,8 & 17 & 6,2 \\
\hline Pogojno perspektivne & 49 & 29,0 & 23 & 22,1 & 72 & 26,4 \\
\hline Zelo perspektivne & 109 & 64,5 & 75 & 72,1 & 184 & 67,4 \\
\hline Skupaj & 169 & 100,0 & 104 & 100,0 & 273 & 100,0 \\
\hline
\end{tabular}

Glede na siceršnjo slabo demografsko sliko slovenskih kmetij je podatek, da je v našem vzorcu sodelovalo kar 67,4 \% kmetij, ki jih odlikuje visoka stopnja demografske vitalnosti, izjemno pozitiven. Podrobnejša primerjava kaže, da se trenutno več ekološko kot konvencionalno usmerjenih kmetij uvršča med vitalne (preglednica 5).

Preglednica 6: Razlike med gospodarji konvencionalnih in ekoloških kmetij glede vizije prihodnjega delovanja kmetije

Table 6: Differences between the heads of conventional and organic farms regarding the vision of the future operation of their farm

\begin{tabular}{|c|c|c|c|c|c|c|}
\hline \multirow[b]{2}{*}{ Bodoči razvoj kmetije } & \multicolumn{2}{|c|}{ Konvencionalne kmetije } & \multicolumn{2}{|c|}{ Ekološke kmetije } & \multicolumn{2}{|l|}{ Skupaj } \\
\hline & $\mathbf{N}$ & $\%$ & $\mathbf{N}$ & $\%$ & $\mathbf{N}$ & $\%$ \\
\hline Nima prave prihodnosti & 9 & 5,4 & 5 & 4,8 & 14 & 5,2 \\
\hline Ostaja v okviru sedanjega & 60 & 35,9 & 40 & 38,5 & 100 & 36,9 \\
\hline Odpirajo se nove možnosti & 98 & 58,7 & 59 & 56,7 & 157 & 57,9 \\
\hline Skupaj & 167 & 100,0 & 104 & 100,0 & 271 & 100,0 \\
\hline
\end{tabular}


Gospodarji anketiranih tržnih kmetij so poročali tudi o subjektivnem pogledu na prihodnji razvoj njihove kmetije (preglednica 6). Razmišljanja oziroma ocene perspektivnosti obeh obravnavanih skupin so zelo podobne: 58,7 \% gospodarjev konvencionalnih ter 56,7 \% gospodarjev ekoloških kmetij ocenjuje, da se v prihodnosti obetajo nove priložnosti za nadaljnji razvoj in rast kmetije.

Za testiranje statistično pomembnih razlik med skupinami anketiranih gospodarjev konvencionalnih in ekoloških tržnih kmetij, mlajših in starejših gospodarjev ter gospodarjev s formalno in neformalno kmetijsko izobrazbo smo uporabili Mann-Whitneyjev neparametrični test. Do pomembne razlike med obravnavanimi kmetijami prihaja le pri deležu dohodka iz kmetijstva: na konvencionalnih kmetijah je delež dohodka iz kmetijstva nižji kot na ekoloških $\left(M_{k o n v}=60,24, S D_{k o n v}=27,17 ; M_{e k o}=67,75, S D_{e k o}=28,73\right)$.

Preglednica 7: Testiranje razlik med mlajšimi $(N=139)$ in starejšimi $(N=134)$ gospodarji anketiranih kmetij o kariernih sidrih

Table 7: Testing differences on career anchors between younger $(N=139)$ and older $(N=134)$ heads of farms

\begin{tabular}{|l|c|c|}
\cline { 2 - 3 } \multicolumn{1}{c|}{} & $\mathbf{z}$ & $\mathbf{p}$ \\
\hline Zadovoljstvo & $-0,263$ & 0,793 \\
\hline Vitalnost & $-3,720$ & $\mathbf{0 , 0 0 0}$ \\
\hline Delež dohodka iz kmetijstva & $-2,098$ & $\mathbf{0 , 0 3 6}$ \\
\hline Vprašalnik kariernih sider & & \\
\hline Tehnično-funkcionalno & $-7,68$ & 0,442 \\
\hline Menedžersko & $-2,156$ & $\mathbf{0 , 0 3 1}$ \\
\hline Samostojnost in neodvisnost & $-1,696$ & 0,090 \\
\hline Varnost in stabilnost & $-1,122$ & 0,262 \\
\hline Predanost & $-1,169$ & 0,243 \\
\hline Izziv & $-1,377$ & 0,168 \\
\hline Življenjski slog & $-0,790$ & 0,430 \\
\hline
\end{tabular}

Legenda: $z=$ Mann-Whitneyjev koeficient; $p$ = statistična pomembnost Legend: $z=$ Mann-Whitney coefficient; $p$ = statistical significance

Analiza je pokazala, da med mlajšimi in starejšimi gospodarji ne prihaja do pomembnih razlik v zadovoljstvu z rezultati, ki jih daje njihova kmetija. Kmetije mlajših gospodarjev so bolj demografsko vitalne $\left(M_{\text {mladi }}=2,77, S D_{\text {mladi }}=0,42 ; M_{\text {stari }}=2,45, S D_{\text {stari }}\right.$ $=0,71)$ ter $\mathrm{s}$ kmetovanjem zaslužijo več denarja kot na kmetijah starejših gospodarjev $\left(M_{\text {mladi }}=66,89, S D_{\text {mladi }}=26,83 ; M_{\text {stari }}=59,41, S D_{\text {stari }}=28,74\right)$. Pri mlajših gospodarjih kmetij se tudi pogosteje pojavlja menedžersko karierno sidro $\left(M_{\text {mladi }}=19,91, S D_{\text {mladi }}=\right.$ 4,$27 ; M_{\text {stari }}=18,74, S D_{\text {stari }}=4,86$ ). Pokazalo se je tudi, da anketiranim kmetijam, katerih gospodarji imajo formalno kmetijsko izobrazbo, kmetijstvo praviloma predstavlja pomembnejši vir dohodka kot kmetijam, kjer so gospodarji brez nje $\left(M_{i z o b}=73,62, S D_{i z o b}=\right.$ 24,$\left.03 ; M_{b r e z}=58,73, S D_{b r e z}=28,76\right)$. Dodatna izobraženost na kmetijskem področju pa ni pokazala razlik pri izraženosti kariernih sider. 
In kakšna je smer ter stopnja povezanosti med karierno usmerjenostjo gospodarja kmetije, demografskimi lastnostmi ter rezultati poslovanja kmetije? Ker se je porazdelitev vključenih spremenljivk statistično pomembno razlikovala od normalne, smo uporabili Spearmanov $\rho$ koeficient korelacije. Korelacijska analiza $(N=273)$ je pokazala, da je menedžersko karierno sidro bolj značilno za mlajše gospodarje kmetije $(r=-0,14 ; p<0,05)$ ter tiste, ki imajo dodatno kmetijsko izobrazbo $(r=0,15 ; p<0,05)$. Lastniki kmetij z bolje izraženim tehnično-funkcionalnim kariernim sidrom so tudi bolj zadovoljni z rezultati, ki jih daje kmetija $(r=0,18 ; p<0,01)$. Prav tako se višja stopnja zadovoljstva povezuje tudi s kariernim sidrom izziva $(r=0,15 ; p<0,05)$. Višja stopnja vitalnosti kmetije pa se povezuje $\mathrm{z}$ bolj izraženim kariernim sidrom življenjski slog $(r=0,12 ; p<0,05)$. Gospodarji kmetije, pri katerih prevladujeta tehnično-funkcionalno sidro $(r=0,26 ; p<0,01)$ ter sidro samostojnosti in neodvisnosti $(r=0,14 ; p<0,05)$, poročajo o višjem dohodku iz kmetijstva.

\section{RAZPRAVA IN ZAKLJUČKI}

Med gospodarji slovenskih tržnih kmetij, vključenimi v našo raziskavo $(N=273)$, prevladujeta sidri varnosti in stabilnosti ter življenjskega sloga. Obe sta značilni za osebe, ki iščejo stabilno in 'predvidljivo delo', ki hkrati nudi tudi relativno trajno delovno razmerje (kar kmetovanje samo po sebi nesporno nudi oziroma zahteva). Bolj jih zanima delo samo po sebi kot pa njegova vsebina. Izražajo željo po delu, ki predstavlja hkrati njihov življenjski stil: kako učinkovito usklajevati lastne potrebe, potrebe družine in kariere. Pomembno jim je, da imajo ob pravem času na voljo prave možnosti (npr. prilagodljiv delovni čas). Rezultati tudi kažejo, da slovenski kmetje razumejo svoje delo kot sestavni del življenja, ga zaradi same narave dela v kmetijstvu spretno vključujejo v svoj način življenja, manj pa ga dojemajo kot izziv in priložnost za spremembe in napredek.

Zanimive so tudi ugotovitve, ki so povezane z usmeritvijo kmetije v ekološko oziroma konvencionalno pridelavo. Pri anketiranih gospodarjih konvencionalnih kmetij je pogosteje prisotno menedžersko sidro, ki izraža željo posameznika po vodenju, sprejemanju odgovornosti in odločanju. Ti gospodarji kmetij določeno specializacijo (npr. ekološko usmeritev kmetije) vidijo kot past. Razumejo nujnost poznavanja področij in sprejmejo dejstvo, da morajo biti najprej izvedenci na svojem področju, če hočejo dobro funkcionirati kot direktorji. Na drugi strani se pri gospodarjih ekoloških kmetij pogosteje pojavlja tehnično-funkcionalno sidro, za katerega je značilno, da se posamezniki predajo specializaciji, se povsem poistovetijo z delom in hkrati podcenjujejo funkcije vodenja. Pogosto gre na začetku večine karier za to sidrno usmerjenost in je njihova zgodnja faza skoraj vedno povezana s specializacijo. Glede na dejstvo, da se ekološki način kmetovanja sistematično uveljavlja pri nas šele dobrih 15 let, je takšna slika logična. Posameznikom s tem kariernim sidrom delo pomeni izziv, radi preizkušajo lastne zmožnosti in spretnosti. Pomembna jim je vsebina dela, ne le delo samo po sebi, za svoje delo in rezultate pa potrebujejo oziroma pričakujejo tudi priznanja drugih (kmetov).

Ugotavljamo, da se karierna sidra med gospodarji konvencionalnih in ekoloških kmetij delno razlikujejo. Ker se po Scheinovi teoriji dokončno oblikujejo v prvih desetih letih kariere, lahko predvidevamo, da se bodo sidra mlajših gospodarjev z leti še delno 
preoblikovala na osnovi razvoja njihove osebnosti, spremembe vrednot ter izkušenj, ki jih bodo gospodarji pridobivali ob rednem delu na kmetiji ter tudi na širšem trgu. Tako v obdobju oblikovanja sider lahko nanje vpliva posameznikovo ožje okolje (starši oziroma drugi sorodniki, ki se že ukvarjajo s kmetijstvom), regija, v kateri posameznik odrašča (npr. območje z dobrimi pridelovalnimi možnostmi, kot sta Pomurska ali deloma Podravska statistična regija), ter tudi širše okolje (npr. informacije iz medijev, izobrazba idr.), iz katerega posameznik dobiva določene spodbude za oblikovanje svojih stališč, vrednot, pričakovanj in načrtov glede nadaljnje usmerjenosti njegove kmetije.

Zanimiva je ugotovitev, da je pogled gospodarjev na razvojno prihodnost kmetij (58 \% vprašanih meni, da se odpirajo nove možnosti) kljub prevladujočim stabilnejšim in 'varnejšim' kariernim sidrom kar optimističen ter odprt za spremembe in novosti.

Glede na večjo izraženost kariernih sider, ki se povezujejo predvsem z iskanjem občutka varnosti in stabilnosti ter željo po usklajevanju dela in zasebnega življenja ob sočasnem pomanjkanju želje po novih izzivih, menimo, da bi bilo dobro v slovenski izobraževalni sistem bolj sistematično dodajati podjetniške vsebine, pa tudi znanja s področja varovanja okolja, zdravja ipd. Zaradi gospodarskih razmer v Sloveniji (in širše v Evropi) se kar nekaj mlajših odloča za opustitev klasičnih kariernih poti in se usmerjajo tudi na področje kmetijstva, vendar se tega izziva pogosteje lotevajo inovativno in drzno, saj niso obremenjeni niti s predhodno izkušnjo niti s pritiski družine. Zanje bi bilo z vidika oblikovanja ustreznih kariernih sider smiselno uvesti nekakšen način mentorstva oziroma izmenjave informacij. Če želimo, da se bo profil zadovoljnega in uspešnega gospodarja kmetije sistematično razvijal in oblikoval tudi v prihodnje, potrebujemo načrten in organiziran pristop k njihovemu kariernemu razvoju. Ta bi moral vključevati sistematično pridobivanje ustreznih novih znanj, upoštevanje želja, oblikovanje ustreznih vrednot in usmerjanje motivov ter zagotovljeno svetovanje v situacijah, ko gospodar potrebuje pomoč na določenem področju.

Gospodarski razvoj kmetije je pomembno odvisen od gospodarja in njegovih osebnostnih lastnosti. Potrebno je upoštevati, da se njegova karierna usmeritev najbolj oblikuje v prvih desetih letih dela. Hkrati je treba vedeti, da so številni gospodarji na kmetiji vpeti $\mathrm{v}$ delo in odločanje na kmetiji že od mladosti in so na nek način bolj kot ostali poklici pod vplivom t. i. ožjega okolja (družine, družinske tradicije), kar pomembno vpliva na njihov osebnostni razvoj.

Spremembe in ukrepe za bolj upravljavsko in inovativno ter konkurenčno naravnanost slovenskega kmeta lahko uvajamo v treh korakih. V prvi fazi je vsekakor pomembno upoštevati zgodnje oblikovanje kariernih sider: na njihovo ustreznejše oblikovanje je smiselno vplivati v okviru izobraževalnega sistema (predvsem na področju formalnega kmetijskega izobraževanja, pa tudi dodatnih kmetijskih izobraževanj). V drugem kora$\mathrm{ku}$ je pomembno tehnično-funkcionalnemu kariernemu sidru (specializacija, vsebinski razvoj dela kmeta) dodati še menedžersko sidro. To pomeni, da bo kmet ne le dober strokovnjak na svojem področju, ampak bo tudi sposoben vodenja, prevzemanja odgovornosti in iskanja pravih možnosti in rešitev. Tretji in najzahtevnejši korak pa pomeni povečanje sposobnosti posameznega kmeta pri premagovanju ovir (npr. neprestane zakonodajne spremembe, spreminjajoče tržne zakonitosti, podnebne spremembe, ki izrazito vplivajo na kmetijski sektor ipd.), zmožnost iskanja priložnosti, ki se porajajo, hkrati pa 
biti pripravljen (v razumnih mejah) nekoliko več tvegati in biti pripravljen (in odziven) na hitre spremembe. Na tem mestu velja opozoriti na najnovejše izsledke antropologinje Knežević Hočevarjeve (2015), ki je v raziskavah med kmeti severovzhodne Slovenije, ki se ukvarjajo z intenzivnim kmetovanjem, prepoznala tveganje in negotovost pri odločanju kot ustvarjalni sili njihovega pozicioniranja v skupnosti, (samo)opredeljevanja, socialnosti, oziroma kot zaviralna dejavnika, ki tlakujeta strah pred neuspehom.

Prepoznano vlogo gospodarjev na kmetiji smo desetletja vrednotili le s podatki o njihovi starosti, izobrazbi in formalni kmetijski izobrazbi. Stopnja izraženosti kariernih sider pri posamezniku nam daje dodatne informacije oziroma vpogled v njegovo osebnost, kar se neposredno in posredno vsakodnevno odraža pri njegovem vedenju, npr. na kakšen način gospodar kmetije sprejema odločitve, se odloča za širitev dejavnosti, načrtuje aktivnosti, upravlja finance in se odloča za sodobne metode kmetovanja.

\section{Opomba}

Projekt Ekonomika ekoloških kmetij v Sloveniji (V7-1118), ki se je izvajal v okviru Ciljnega raziskovalnega programa v obdobju 2011-2013, sta sofinancirala Ministrstvo za kmetijstvo, gozdarstvo in prehrano ter Javna agencija za raziskovalno dejavnost Republike Slovenije.

\section{Viri in literatura}

Akcijski načrt razvoja ekološkega kmetijstva v Sloveniji do leta 2015 (ANEK). 2005. Ministrstvo za kmetijstvo, gozdarstvo in prehrano, Ljubljana, 72 str. URL: http:// www.mkgp.gov.si/fileadmin/mkgp.gov.si/pageuploads/podrocja/Kmetijstvo/Ekolosko_kmetijstvo/ANEK_slo.pdf(Citirano 12.5. 2015).

Analiza stanja ekološkega kmetovanja. 2015. Ministrstvo za kmetijstvo, gozdarstvo in prehrano, 2015. URL: http://www.mkgp.gov.si/si/delovna_podrocja/kmetijstvo/ekolosko_kmetovanje/analiza_stanja_ekoloskega_kmetovanja/ (Citirano 12. 5. 2015).

Bohak, Z., 2011. Analiza stanja nasledstva in ocena nasledstvene perspektivnosti slovenskih družinskih kmetij. Doktorska disertacija. Maribor, Fakulteta za kmetijstvo in biosistemske vede, 187 str. URL: http://dkum.uni-mb.si/Dokument.php?id=20992 (Citirano 15. 6. 2015).

Brečko, D., 2004. Karierna sidra kot model za usmerjanje kariere. HRM: strokovna revija za ravnanje z ljudmi pri delu, 2, 3, str. 32-37.

Brečko, D., 2006. Načrtovanje kariere kot dialog med organizacijo in posameznikom. Ljubljana, Planet GV, 331 str.

Brečko, D., 2008. Karierna sidra kot instrument za načrtovanje kariere: povej mi, katero sidro imaš in povem ti, kakšna bo tvoja kariera. HRM: strokovna revija za ravnanje z ljudmi pri delu, 6, 25, str. 24-29.

Butler, T., Waldroop, J., 1999. Job sculpting: the art of retaining your best people. Harvard business review, 77, 5, str. 144-152. 
Coetzee, M., Schreuder, D., 2009. Psychological career resources as predictors of working adults' career anchors: an exploratory study. SA Journal of industrial psychology, 35, 1, str. 117-127.

DeLong, T. J., 1982. Re-examining the career anchor model. Personnel, 59, str. 51.

Feldman, D. C., Bolino, M. C., 1996. Careers within careers: reconceptualising the nature of career anchors and their consequences. Human resource management review, 6, 2 , str. 89-112. DOI: 10.1016/S1053-4822(96)90014-5

Gassner, B., Freyer, B., Leitner, H., 2008. Labour quality model for organic farming food chains. V: Neuhoff, D. in sod. (ur.). Cultivate the future: cultivating the future based on science, 2. knj., str. 400-403.

Jansen, K., 2000.Labour, livelihoods, and the quality oflife in organic agriculture. Biological agriculture \& horticulture, 17, 3, str. 247-278. DOI: 10.1080/01448765.2000.9754845

Jiang, J. J., Klein, G., Balloun, J. L., 2001. The joint impact of internal and external career anchors on entry-level IS career satisfaction. Information \& management, 39, 1, str. 31-39. DOI: 10.1016/S0378-7206(01)00077-5

Klemenčič, M. M., Lampič, B., Potočnik Slavič, I., 2008. Življenjska (ne)moč obrobnih podeželskih območij v Sloveniji. GeograFF, 3. Ljubljana, Znanstvena založba Filozofske fakultete, Oddelek za geografijo, 149 str. URL: http://geo.ff.uni-lj.si/sites/ default/files/users/geostud/geograff_3.pdf(Citirano 15. 6. 2015).

Knežević Hočevar, D., 2015. »Kdor ne tvega, ni kmet!« K antropologiji tveganja in negotovosti. Glasnik Slovenskega etnološkega društva, 55, 3-4, str. 61-69.

Kniveton, B. H, 2004. Managerial career anchors in a changing business environment. Journal of European industrial training, 28, 7, str. 564-573.

Lampič, B., 2005. Kmetijstvo kot priložnost sonaravnega razvoja podeželja v Sloveniji. Dela, 23, str. 167-219. URL: http://revije.ff.uni-lj.si/Dela/article/view/dela.23.4.167219 (Citirano 15. 6. 2015).

Lampič, B., 2008. Kmetijstvo v Mestni občini Ljubljana: relikt ali razvojni potencial. GeograFF, 2. Ljubljana, Znanstvena založba Filozofske fakultete Univerze v Ljubljani, Oddelek za geografijo, 125 str. URL: http://geo.ff.uni-lj.si/sites/default/files/geograff_2.pdf (Citirano 15.6.2015).

Lampič, B., Slabe, A. 2013. Tržna pridelava na ekoloških kmetijah kot dejavnik razvoja na podeželju. V: Nared, J., Perko, D., Razpotnik Visković, N. (ur.). Nove razvojne perspektive. Ljubljana, Založba ZRC, str. 111-125.

Lampič, B., Slabe, A., Mrak, I., Šebenik, U., 2013. Ekonomika ekoloških kmetij v Sloveniji. Končno poročilo (del UL FF in ITR), CRP 2011-2013. Ljubljana, Oddelek za geografijo FF in Inštitut za trajnostni razvoj, 56 str.

Nienaber, B., Potočnik Slavič, I., 2013. Is diversification of farm households still an option for integrated rural development? Evidence from Slovenia and Saarland, Germany. Quaestiones Geographicae, 32, 4, str. 39-48. URL: http:/www.degruyter.com/view/j/quageo.2013.32.issue-4/quageo-2013-0032/quageo-2013-0032.xml (Citirano 20. 11. 2015).

Nordvik, H., 1996. Relationship between Holland's vocational typology, Schein's career anchors and Mayer-Briggs types. Journal of occupational and organisational psychology, 69, 3, str. 263-275. DOI: 10.1111/j.2044-8325.1996.tb00614.x 
Offermann, F., Nieberg, H., 2000. Economic performance of organic farms in Europe. Organic farming in Europe: economics and policy, 5, 198 str. URL: https://www. uni-hohenheim.de/i410a/ofeurope/organicfarmingineurope-vol5.pdf (Citirano 15. 6. 2015).

Organic marketing initiatives and rural development, 2004. V: Schmid, O., Sanders, J., Midmore, P. (ur.). Aberystwyth, School of Management and Business, University of Wales, 200 str.

Popis kmetijskih gospodarstev, Slovenija, 2000 in 2010. Statistični urad Republike Slovenije (SURS). URL: http://pxweb.stat.si/pxweb/Database/Kmetijstvo_2010/Kmetijstvo_2010.asp (Citirano 12.5.2015).

Popis kmetijstva 2010. Statistični urad Republike Slovenije (SURS). URL: http:/www. stat.si/StatWeb/glavnanavigacija/podatki/prikazistaronovico? IdNovice $=4594$ (Citirano 12. 5. 2015).

Potočnik Slavič, I., 2010. Vključevanje kmetov v oskrbne verige: primer dopolnilnih dejavnosti na slovenskih kmetijah. Dela, 34, str. 5-22. DOI: 10.4312/dela.34.1.5-22

Schein, E. H., 1974. Career anchors and career paths: a panel study of management school graduates. Technical report No. 1. Cambridge: Sloan School of Management, MIT. URL: http://dspace.mit.edu/bitstream/handle/1721.1/1878/SWP-0707-02815445.pdf (Citirano 12. 5. 2015).

Schein, E. H., 1978. Career dynamics: matching individual and organizational needs. Reading (MA), Addison-Wesley, 176 str.

Schein, E. H., 1990. Career anchors: discovering your real values. San Diego (CA), Pfeiffer \& Co, 87 str.

Schein, E. H., 1996. Career anchors revisited: implications for career development in the 21 st century. The Academy of Management Executive, 10, 4, str. 80-88.

Shreck, A., Getz, C., Feenstra, G., 2006. Social sustainability, farm labor, and organic agriculture: findings from an exploratory analysis. Agriculture and human values, 23, 4, str. 439-449.

Slabe Erker, R., Lampič, B., Cunder, T., Bedrač, M., 2015. Opredelitev in merjenje trajnosti v kmetijstvu. GeograFF, 16. Ljubljana, Znanstvena založba Filozofske fakultete, Oddelek za geografijo, 154 str.

Slabe, A., 2015. Razvojni potencial ekološkega kmetijstva v Sloveniji v povezavi z doseganjem trajnostne samooskrbe s hrano. Doktorska disertacija. Ljubljana, Filozofska fakulteta, Interdisciplinarni študijski program Varstvo okolja, 203 str.

Slabe, A., Lampič, B., Juvančič, L., 2011. Potenciali ekološke pridelave za trajnostno lokalno oskrbo s hrano v Sloveniji. Dela, 36, str. 93-109. DOI: 10.4312/dela.36.5.93-109

Slabe, A., Kuhar, A., Juvančič, L., Tratar Supan, A. L., Lampič, B., Pohar, J., Gorečan, M., Kodelja, U., 2010. Analiza stanja in potencialov za rast ponudbe ekoloških proizvodov v luči doseganja ciljev Akcijskega načrta za razvoj ekološkega kmetijstva v Sloveniji do 2015. Zaključno poročilo. Biotehniška fakulteta, Oddelek za zootehniko in Inštitut za trajnostni razvoj, 78 str.

Suutari, V., Taka, M., 2004. Career anchors of managers with global careers. Journal of management development, 23, 9, str. 833-847. DOI: 10.1108/02621710410558440 


\section{SAFETY, STABILITY AND LIFESTYLE: DOMINANT CAREER ANCHORS AMONG THE HEADS OF SLOVENIA'S MARKET ORIENTATED AGRICULTURAL HOLDINGS}

\section{Summary}

The main purpose of the survey was to identify the key personal characteristics of market-oriented farmers (heads of agricultural holdings) in Slovenia. The survey used career anchors as measuring parameters because these comprise most of the personal characteristics and traits required to describe the heads of agricultural holdings. Another objective of the survey was to research and describe the role of career anchors in the development of agricultural holdings, as well as to identify the differences between conventional and organic farmers.

The survey included 273 heads of agricultural holdings in Slovenia, of whom 169 were engaged in conventional farming and 104 in organic farming. We included agricultural holdings that qualified as market-oriented, at least in certain segments, because the development of this sector is strongly linked to agriculture's production role. The Target research programme survey Economics of organic farming in Slovenia included separate questionnaire which, through the use of dominant career anchors, helped describe the personal characteristics of heads of agricultural holdings. The seven career anchors were as follows: the technical-functional anchor, managerial anchor, autonomy and independence anchor, security and stability anchor, mission and devotion anchor, challenge anchor and lifestyle anchor. The survey also garnered basic information from farmers on the characteristics of the agricultural holdings and their heads. The heads were asked for their views on the future of their agricultural holdings and were then requested to evaluate their personal satisfaction with the performance of their holdings.

The results reveal that the career anchor most commonly expressed by heads of marketoriented agricultural holdings was the security and stability anchor, followed by the lifestyle anchor and the autonomy and independence anchor. Heads of agricultural holdings generally seek jobs that provide long-term safety coupled with stable and predictable working conditions. The technical-functional anchor was referred more often among heads of organic agricultural holdings. This anchor typically encourages farmers to develop a high level of expertise in their particular area and underlines the importance of the technical and substantive aspects of their work. Both of the groups surveyed also made frequent references to the lifestyle anchor, which reflects a desire to evolve a healthy balance between work and private life. The fewest references were found to be made to the challenge anchor, which generally indicates that the heads of agricultural holdings feel little need to be challenged. They rarely aspire to venture into new areas or try new working methods.

The survey also shows that heads of agricultural holdings are optimistic about the future development of their farms. Despite the dominance of the stability and security career anchors, $58 \%$ of the respondents reported seeing new development opportunities for their holdings. Slovenian farmers consider their work to be an integral part of their lives. The very nature of farming requires them to integrate this activity skillfully in their lifestyles, and they see it less as a challenge or an opportunity for change and progress. 
The implementation of the changes and measures required for Slovenian farmers to adopt a more managerial, innovative and competitive approach can be achieved in three steps. In the first step, it is vital to take into account the early formation of career anchors and to achieve that career anchors are better integrated within the framework of the educational system, particularly in the areas of formal and supplementary agricultural education. In the second step, the technical-functional anchor (which covers specialisation and the substantive development of a farmer's work) must be combined with the managerial anchor. This means that a farmer not only has to possess a high level of expertise in his area of work, but also managerial skills and the ability to assume responsibility and find the right opportunities and solutions. The third and most demanding step is to increase the farmers' ability to deal with obstacles. Constant changes to legislation, the ever-changing laws of the market and climate changes have a significant impact on the agricultural sector. Farmers should seek new, emerging opportunities, and at the same time to be prepared, within reason, to assume more risks and respond adequately to rapid change.

(Translated by Amidas, d.o.o.) 